\title{
Effect of Fishery Closure on Discard Composition of Rapa Whelk, Rapana venosa (Valenciennes 1846) Beam Trawl Fisheries in Black Sea
}

\author{
Gökhan Erik $^{1 *}$, Murat Dağtekin ${ }^{1}$ \\ ${ }^{1}$ Central Fisheries Research Institute, Trabzon, Türkiye.
}

\begin{abstract}
How to cite
Erik, G., Dağtekin, M. (2022). Effect of Fishery Closure on Discard Composition of Rapa Whelk Beam Trawl Fisheries in Black Sea. Turkish Journal of Fisheries and Aquatic Sciences, 22(5), TRJFAS19046. http://doi.org/10.4194/TRJFAS19046
\end{abstract}

\section{Article History}

Received 25 January 2021

Accepted 19 December 2021

First Online 21 December 2021

\section{Corresponding Author \\ Tel.: +904623411053 \\ E-mail: gokhanerik@gmail.com}

\section{Keywords}

Rapana venosa

Discard

Fishing closure

Fisheries management

Black Sea

\begin{abstract}
Rapa whelk has become significant commercially, as there is a market that makes it export-oriented species. It has also gained special importance because of catching this species in all riparian countries in the Black Sea basin. The various exploitation methods of this species include beam trawl and diving. Here, the experimental beam trawl survey for Rapa whelk fishing was designed monthly in one year. Catch composition was examined spatially and temporally. Differences in estimated biomass of Rapa whelk and abundance of discard species were used to evaluate the effectiveness of seasonal fishing closure. Our results indicated that, discard composition of Rapa whelk fishery strongly reflected seasonal changes. Total estimated abundance and biomass values showed significant regional, seasonal and depth-related differences, also number of species and diversity index changes regionally and seasonally. Discard ratio was found very low in biomass. At the same time, seasonal fishery closure period was benefited for discard species in spring and summer period. The lowest distribution of Rapa whelk and discard species except blood cockle were found in winter season during fishing period. It becomes apparent that seasonal fishery closure is an important management measure both for stock sustainability, species diversity, and ecosystem health. Therefore, all Black Sea countries should consider similar management
\end{abstract}

\section{Introduction}

Discard is defined as the portion of marine animals and plants caught in fishing and thrown back into the sea (Sarda et al., 2013). Fishing discard has been recognized as a serious problem for the last two decades. According to Pérez et al. (2019) annual discards from worldwide marine capture fisheries were 9.1 million tonnes between 2010 and 2014, accounting for $10.8 \%$ of the annual average catch from 2010 to 2014. Due to the growing understanding of its adverse effects on marine ecosystems, accidental catch and discarding have received considerable attention in recent world fisheries research. Today, good fisheries management is defined as serious consideration on ecosystem health and providing the necessary regulations to reduce waste.
The throwing problem poses several related subproblems for social, economic and environmental goals. While usage of trawling and dredging is very common in fishery, they are accounted for about half of the total fish discards worldwide. Especially, bottom trawling causes serious chronic and widespread problems in the benthic zone due to the removal of the growing epifauna, damage and displacement of the habitat and benthic life (Connolly \& Kelly, 1996).

The Rapa whelk species, Rapana venosa Valenciennes 1846, is an invasive alien species in the Black Sea ecosystem which was introduced in 1940s from its origin Asian Pacific waters (ICES, 2004). It is thought thanks to ship ballast water and aquaculture transfer native East Asian seas towards Europe and America (Savini et al., 2007). It was successful in its new 
environment and became widespread as a notorious predator which feeds on oysters, mussels and other bivalves, and thus exerts a major influence on local populations. During 1980s, in response to an international demand for Rapa whelk, a massive fishery emerged in Turkish waters, and along the Bulgarian coast which helped reduce its predation impact on prey species (Bilecik, 1990). In the Black Sea, Turkey harvests the half of its total catch, and majority of the rest is contributed by Bulgaria and Romania (STECF, 2017). While its catch notably increased in 1990s, number of fishing vessels engaged with its fishery also quickly increased (Erik et al., 2020).

During beam trawl operation, turbot, scorpion fish, horse mackerel, goby fish, sole, ray, sea horse, juvenile gurnard, crabs, mussels, prawns, shrimp and native small whelk were caught as discards (Celik \& Samsun, 1996; Düzgüneş, 2001). Estimated discard ratios by abundance in the Black Sea range from 7.5 in Bulgaria (Kelleher, 2005) to 11.4\% in Turkey (Eryasar et al., 2018). Recent studies pointed out diminishing of turbot population are closely related with increase in beam trawling (Petrova-Pavlova et al., 2020). General Fisheries Commission of Mediterranean (GFCM) severally emphasizes the importance of discard studies for commercial stocks in the Black Sea (GFCM, 2019).

Rapa whelk fishing in the Turkish Black Sea EEZ is constituted $45 \%$ from western part and $55 \%$ percent from the eastern. Fishing methods include beam trawl, diving, and rarely pots and traps, however, main fishing is via beam trawling (85\%). In 2018, 725 fishing vessels were registered with daily operation of 9 hours during daylight, and approximately 125 active days in one fishing season (BSGM, 2018, Dağtekin et al., 2018). Although the Rapa whelk fishery is important due to its increasing revenue for Black Sea countries, Turkey is the only one applying several management measures both spatially and temporally for its catch. According to
Turkish fishery circular, its fishery is only permitted to operate at a minimum distance of $500 \mathrm{~m}$ from shore with $4 \mathrm{~m}$ maximum dredge length and $72 \mathrm{~mm}$ minimum mesh size. The beam trawls are prohibited to target Rapa whelk between 15 April -1 September annually to protect this species' spawning season (BSGM, 2020). Other methods like hookah diving or pots are used in summer months as this species is known to be aggregated in the shores with great numbers (Saglam et al., 2017).

Here, the experimental beam trawl survey for Rapa whelk fishing were designed monthly in one year period. Catch composition were examined spatially and temporally. Differences in estimated biomass of Rapa whelk, and abundance of discard species were used to evaluate the effectiveness of seasonal fishing closure.

\section{Materials and Methods}

Study was performed by participation as an observer in a commercial fishing vessel called "Özşahin" with length of overall (LoA) $8 \mathrm{~m}$ with $83 \mathrm{HP}$. A typical beam trawl with $72 \mathrm{~mm}$ mesh size, $40 \mathrm{~cm}$ mouth in depth, and overall size $300 \mathrm{~cm}$ in height were used for sampling (Figure 1). Rapa whelk fishery is almost closed from December to March due to very low catch and very low meat ratio while meat ratio is very high in summer. Still, market demand and some optimal conditions for its occurrence may change these periods. In this study, fishing vessel was officially permitted for research during seasonal closure period in 2018. All specimens obtained during each fishing haul were sorted, identified, counted and weighted. At least 100 Rapa whelk individual were chosen as subsample from each haul to perform length measurements. If the number is low, all specimens were measured. Length measured to the nearest $0.1 \mathrm{~cm}$.

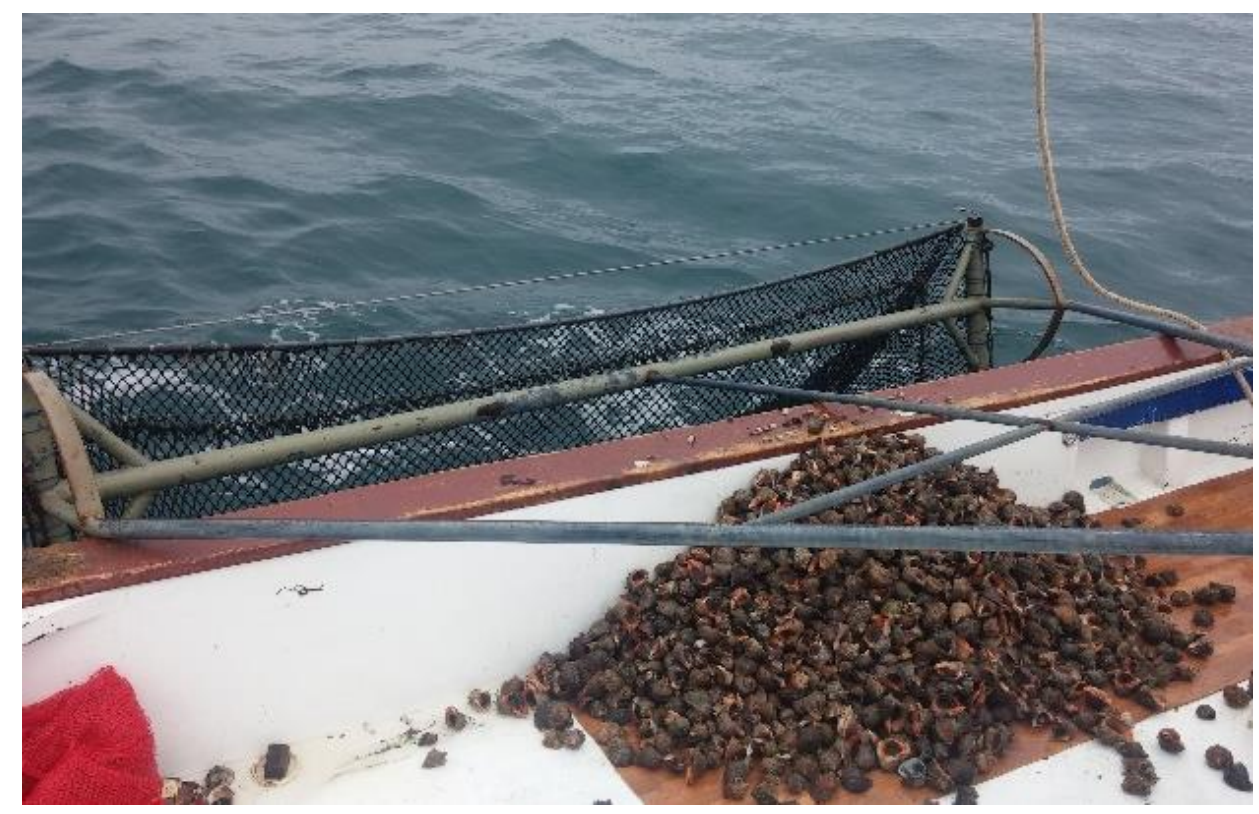

Figure 1. Beam trawl with Rapa Whelk caught in one haul. 


\section{Statistical Analysis}

Statistical analysis were performed for Rapa whelk estimated biomass $\left(\mathrm{kg} . \mathrm{km}^{-2}\right)$, discard estimated biomass, and abundance (ind. $\mathrm{km}^{-2}$ ) according to sampling season, depth and location.

Non-parametric multivariate techniques were used to determine the spatial and temporal patterns of discard species distribution and abundance. Species abundance data were transformed $(\log x+1)$ to construct a similarity matrix using the Bray-Curtis coefficient of similarity. First analysis of similarity (ANOSIM) were applied to five established factors "Region", "Season", "Depth", "Distance" from shore, and "Closure" to determine their significance level (Table 1). Significant factors were then analyzed for similarity of percentages (SIMPER) to identify responsible species for dissimilarities between groups. Non-parametric multidimensional scaling (n-MDS) were used to understand species distribution patterns by estimating them as vector which corresponds over 0.5 correlations (Clarke and Warwick, 2001). Group linkage for Bray-Curtis similarities were used for cluster analysis.

The collected data allowed estimating discard abundance $(N)$, number of species $(S)$, and the Shannon diversity index $\left(H^{\prime}\right.$, bits). Discard species were categorized into five systematic groups according to their classes, i) Bivalvia, ii) Gastropoda, iii) Crustacea, iv) Teleostei, v) Elasmobranchii. In order to determine the level of significance for variables $\left(B, N, S\right.$ and $\left.H^{\prime}\right)$ according to established factors Levene's test for ANOVA were used to identify homogeneity of variance. Non-significant variables were then analyzed for nonparametric Kruskal-Wallis test. Tukey HSD test were used as post-hoc analyze for each factor to understand which groups are significantly different. Univariate and multivariate analyses were applied using PRIMER v7.1.10. ANOVA were analyzed in $R$ ( $R$ Core team, 2020).

\section{Results}

\section{Evaluation of $\boldsymbol{R}$. venosa Distribution}

During sampling period, 71 trawling operation were achieved. Rapana venosa were sampled in all operations. Total lengths ranged from $1.0 \mathrm{~cm}$ to $10.5 \mathrm{~cm}$, average length was found $4.8 \mathrm{~cm}$ (Figure 2). According to literature, size-at-maturity for this species is given 4.4 $\mathrm{cm}$ (Sağlam et al., 2009) which shows almost 25\% percent of the samples were immature in this study.

Highest estimated biomass was found in Station 2 while the lowest were in Station 4 (Figure 2). Regional distribution of $R$. venosa were significantly different ( $p<0.05$; Table 2 ) caused by the lowest value in St.4 (Tukey HSD, $p<0.05$ ) while no other regional differences were found. There is no seasonality in $R$. venosa biomass among summer, spring and autumn except winter when the lowest biomass were observed and showed significant difference (Tukey HSD, $p<0.01$; Figure 3, Table 2). Average biomass were higher in fishery closure period than fishing period and significant difference were found between them (Kruskal-Wallis, $p<0.001$; Table 2, Figure 3). Biomass estimation shows no significant differences on depth strata and distance from shore ( $p>0.05$; Table2). Still, its distribution was higher around 5-20 m depth, and was more stable in amount in the closest area to the shore $(0-150 \mathrm{~m})$ than the outermost distance (Figure 3).

Table 1. Identified factors and their explanations used in analysis of discard distribution.

\begin{tabular}{|c|c|c|c|}
\hline Factor & Codes & & Correspond \\
\hline \multirow{6}{*}{ Region } & St1 & Station 1 & Yoroz \\
\hline & St2 & Station 2 & Kerem \\
\hline & St3 & Station 3 & Vakfıkebir \\
\hline & St4 & Station 4 & Mersin \\
\hline & St5 & Station 5 & Çarşıbaşı \\
\hline & St6 & Station 6 & Yalıköy \\
\hline \multirow{4}{*}{ Season } & $\mathrm{Au}$ & Autumn & September-November \\
\hline & Wi & Winter & December-January-February \\
\hline & Sp & Spring & March-April-May \\
\hline & $\mathrm{Su}$ & Summer & June-July-August \\
\hline \multirow{5}{*}{ Depth } & $5-10 m$ & & \\
\hline & $10-15 \mathrm{~m}$ & & \\
\hline & $15-20 \mathrm{~m}$ & & \\
\hline & $20-25 \mathrm{~m}$ & & \\
\hline & $25-30 \mathrm{~m}$ & & \\
\hline \multirow{5}{*}{ Distance } & $0-100 \mathrm{~m}$ & & \\
\hline & $100-150 \mathrm{~m}$ & & \\
\hline & $150-250 \mathrm{~m}$ & Distance from shore & Shelf structure \\
\hline & $250-400 \mathrm{~m}$ & & \\
\hline & $400 \mathrm{~m}>$ & & \\
\hline \multirow{2}{*}{ Closure } & Non-fishing & 15 April - 31 August & \\
\hline & Fishing & 1 September - 14 April & Seasonal fishing ban in Turkish EEZ in Black Sea \\
\hline
\end{tabular}




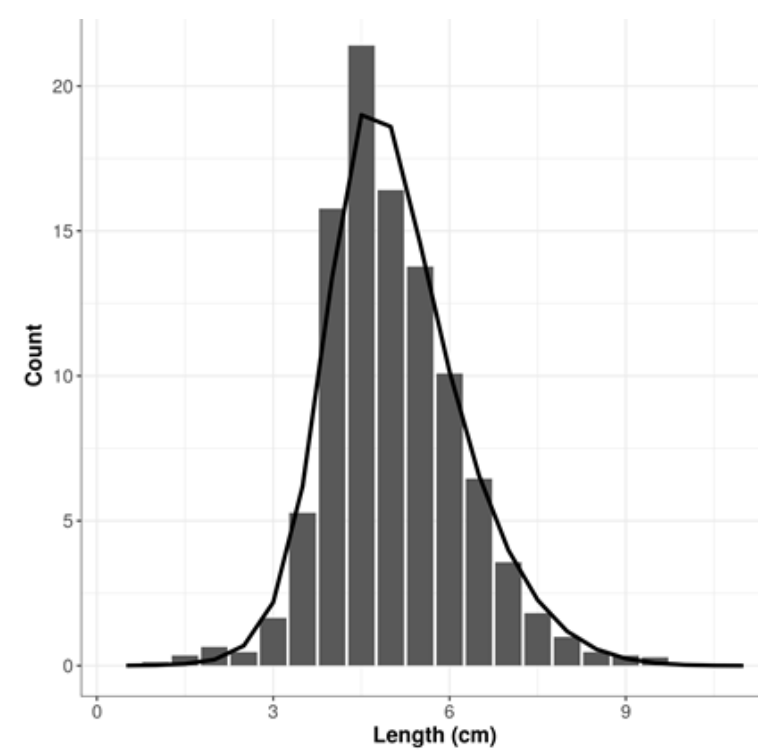

Figure 2. Overall length frequency distribution of $R$. venosa during sampling period.
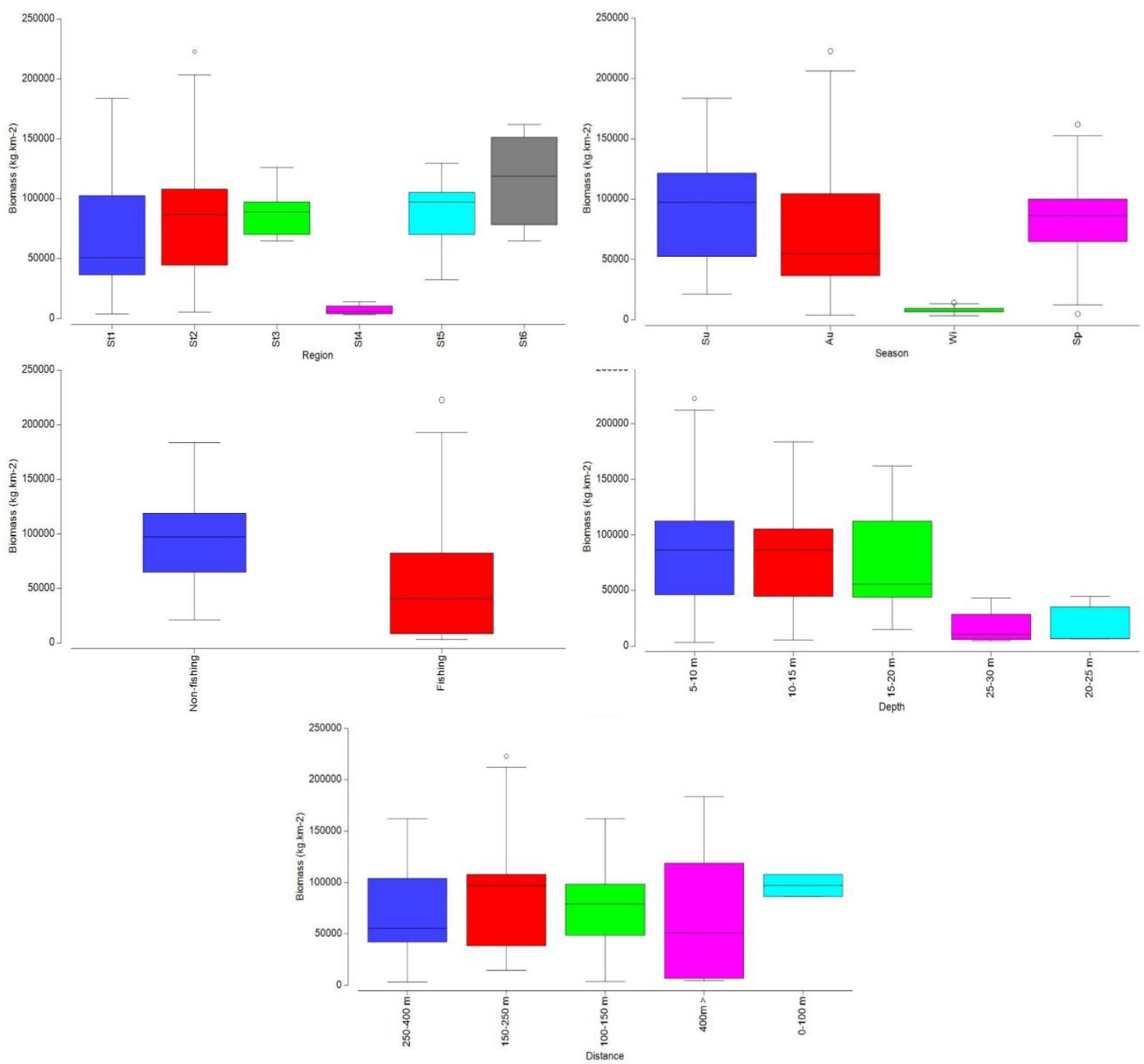

Figure 3. Box plots of estimated abundance of $R$. venosa with $95 \% \mathrm{Cl}$ according to sampling region, season, depth, distance from shore and fishery closure period in the Black Sea. 


\section{Discard Composition During Rapana venosa Survey}

Overall catch composition during one year sampling showed estimated biomass for $R$. venosa constituted $99 \%$ of catch and discarded species were $1 \%$ (Figure 4). Total $R$. venosa biomass was estimated 674 ton per area while total discard biomass was estimated 7.5 ton per area. Estimated Rapana venosa biomass ranged from 4.5 ton. $\mathrm{km}^{-2}$ with the lowest in December and 125 ton. $\mathrm{km}^{-2}$ in June, with average of 61 ton. $\mathrm{km}^{-2}$. On the other hand, estimated discard biomass were found the lowest in June $\left(0.24\right.$ ton. $\left.\mathrm{km}^{-2}\right)$ and 2.49 ton. $\mathrm{km}^{-2}$ in May, with average of 0.68 ton. $\mathrm{km}^{-2}$. Opposite relation were found between Rapa whelk and discard estimations.

For a closer look to the distribution of discard composition, very different distributional pattern than $R$. venosa were noticed in the sampling area and period. Highest estimated discard biomass and abundance were found in St.3, also average values are higher in St. 6 while the lowest were in Station 4 (Figure 5). Regional discard distribution were significantly different $(p<0.05$; Table 2), caused by the highest values in St.5 and St. 6 (Tukey HSD, $p<0.05$ ). There was a strong seasonality in biomass and abundance of discard showed significant difference in spring by very high values (Tukey HSD, $p<0.01$; Table 2 ). Biomass was the lowest during summer while abundance was the lowest during winter (Figure 5).

Discard distribution between seasonal fishery closure and fishing period also show significant difference ( $p<0.05$; Table 2 ) while very high abundance and biomass observed during closure period (Figure 5). Abundance and biomass were found significantly different according to depth and distance factors $(p<0.05$; Table 2). Samplings from the 10-20 m depths constituted main distribution of discards with higher values (Figure 5). Around the closest area to the shore (0-150 m), discard distribution were found very low. The highest values were detected around the outermost sampling area $(>400 \mathrm{~m})$, also average values were found much higher than other distance from the shore (Figure 4).

\section{Composition of Discard Species}

Discard species in the Eastern Black Sea belonged to 25 taxa. Of these, 22 were identified to the species level level (Scapharca inaequivalvis (Bruguière, 1789), Chamalea gallina (Linnaeus, 1758), Cerithium vulgatum (Bruguière, 1792), Tritia reticulata (Linnaeus, 1758), Mytilus galloprovincialis (Lamarck, 1819), Raja clavata (Linnaeus, 1758), Dasyatis pastinaca (Linnaeus, 1758), Ophidium barbatum (Linnaeus, 1758), Mullus barbatus (Linnaeus, 1758), Scorpeana porcus (Linnaeus, 1758),Uranoscopus scaber (Linnaeus, 1758), Pegusa nasuta (Pallas, 1814), Neogobius melanostomus (Pallas, 1814), Arnoglossus kessleri (Schmidt, 1915), Parablennius tentacularis (Brünnich, 1768), Hippocampus hippocampus (Linnaeus, 1758), Liocarcinus depurator (Linnaeus, 1758), Liocarcinus navigator (Herbst, 1794), Brachynotus sexdentatus (Risso, 1827), Eriphia verrucosa (Forskål, 1775), Carcinus aestuarii (Nardo, 1847), Plimnus hirtellus (Linnaeus, 1761)), and three to genus level (Syngnathus sp., Gibbula sp., Callionymus sp.). Most abundant species was another invasive bivalve Scapharca inequivalvis (72\%), following by a decapod species Liocarcinus depurator (10\%), and a commercially important bivalve Chamelea gallina (7\%) (Figure 6a). Dominant species order were changed in estimated biomass values, as a small species in weight, Chamelea gallina were not dominant, but teleosts Scorpaena porcus (6\%) and Uronoscopus scaber (5\%) placed after S. inequivalvis and L. depurator (Figure 6b).

Diversity indicators of discard composition were considered according to regional, seasonal and depth related factors. Numbers of species $(S)$ in the discard composition were the highest during summer season, and in the shallowest area. Although, $S$ gradually decreased by depth, the closest area to the shore has the lowest values. Seasonal closure period that covers summer period also has higher values. Only regional and seasonal differences were found significant for $S$ (Kruskal-Wallis, $\mathrm{p}<0.001$; Table 2). An important diversity indicator, the Shannon diversity index $\left(H^{\prime}\right)$

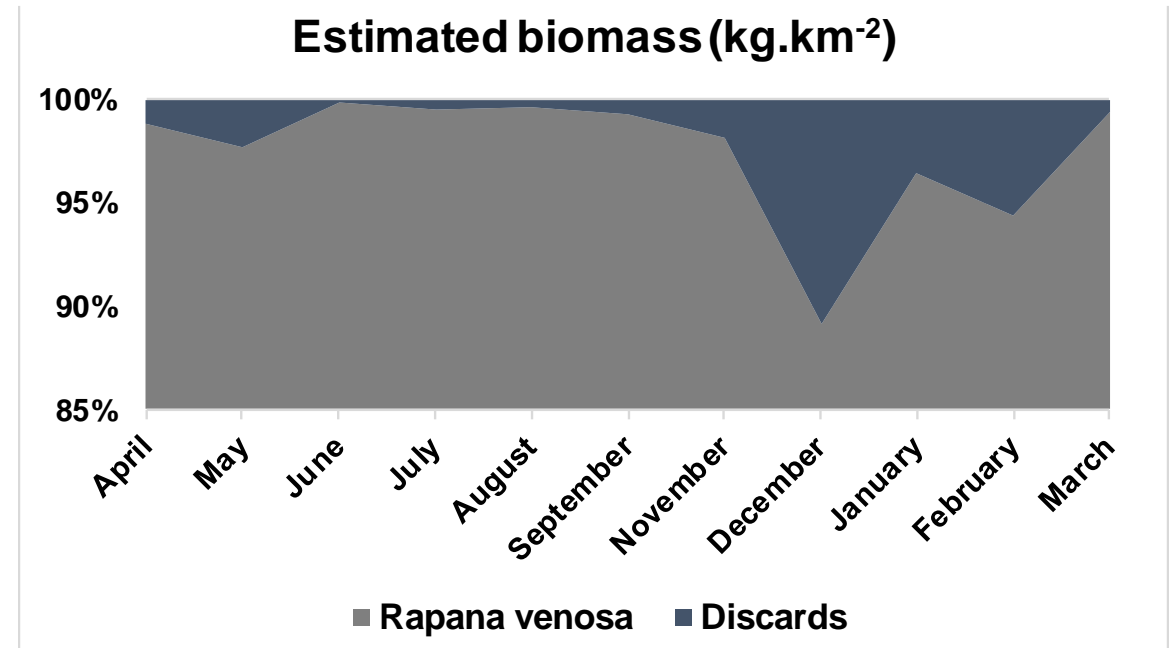

Figure 4. Monthly changes in percentage of a) estimated biomass and of $R$. venosa and discards during beam trawl sampling. 

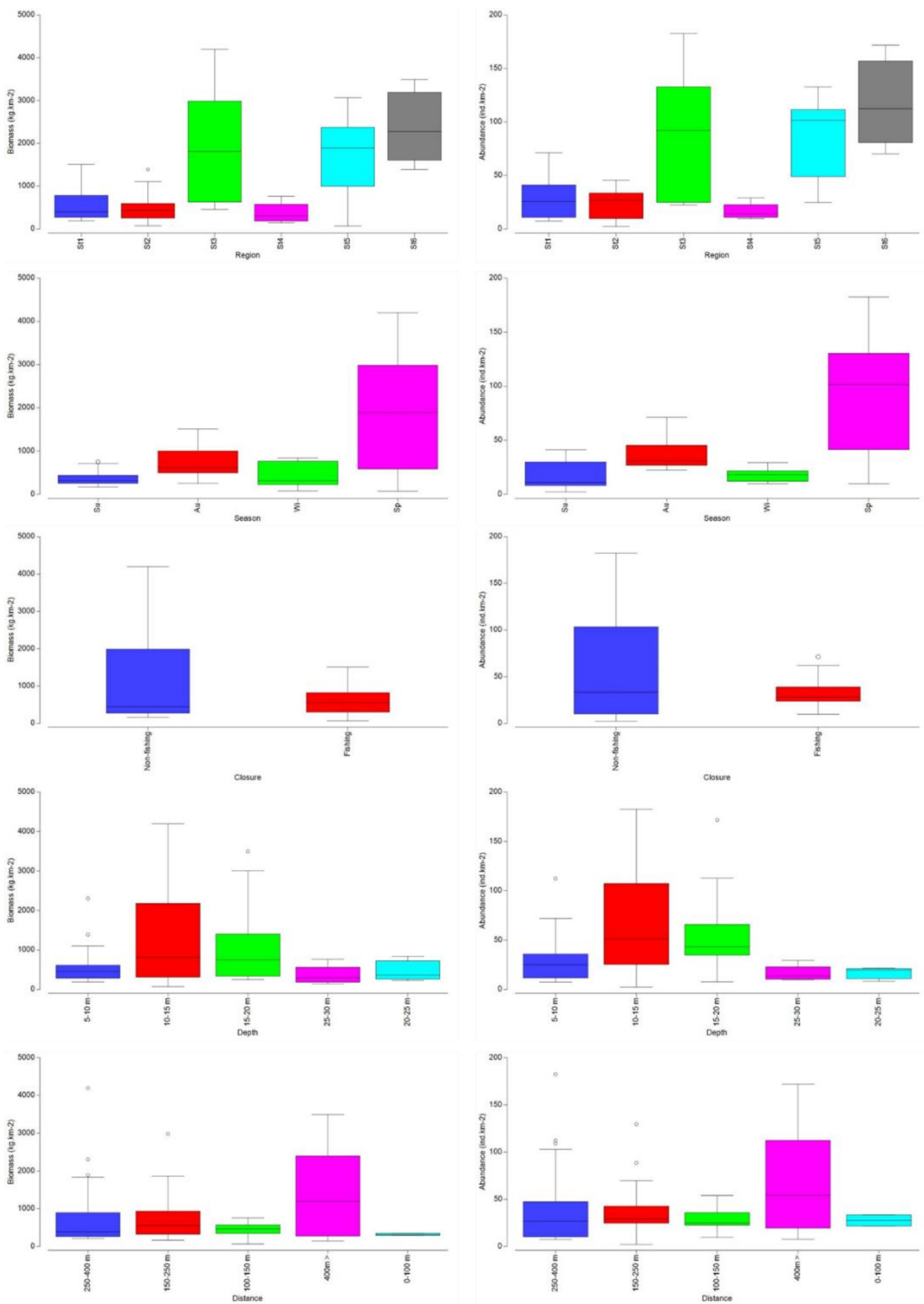

Figure 5. Box plots of estimated total discard abundance and biomass with $95 \% \mathrm{Cl}$ according to sampling region, season, depth, and distance from shore and fishery closure period in Eastern Black Sea. 

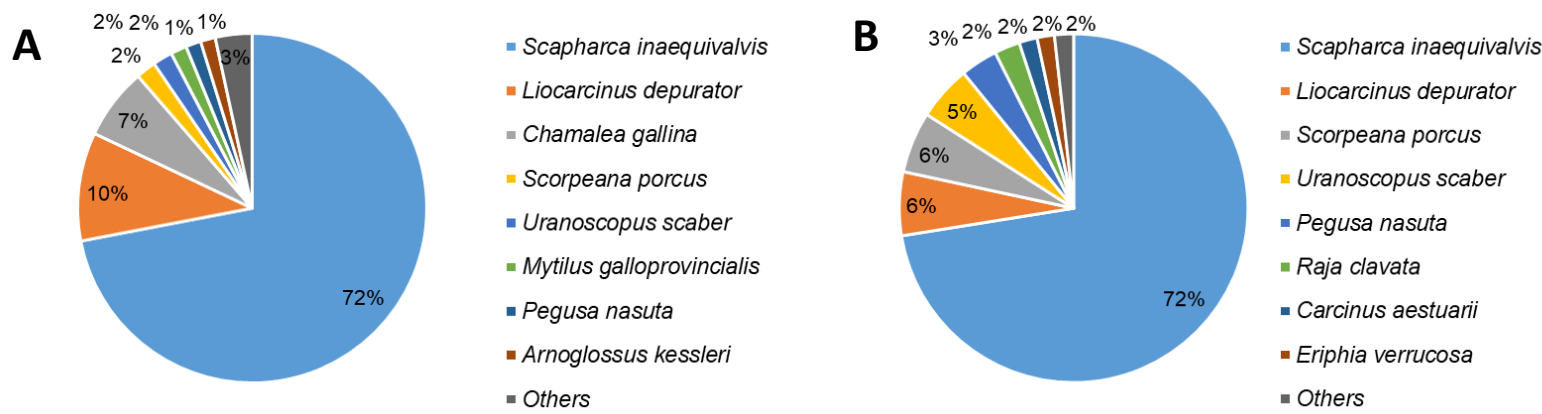

Figure 6. Dominant species of discard composition in a) estimated total abundance, and b) estimated total biomass.

Table 2. Levene's test results for significance levels of differences in Rapa whelk estimated total biomass, estimated total discard biomass and total abundance in closure and non-closure period. Kruskal-Wallis test results for non-parametric variables, species number $(S)$ and the Shannon diversity index $\left(H^{\prime}\right)$ among factors. Significance level were marked with $(*$ for $p<0.05$; and $* *$ for $p<0.001)$.

\begin{tabular}{|c|c|c|c|c|}
\hline \multirow{2}{*}{ Variables } & S.S. & d.f. & $F$ & $p$ \\
\hline & \multicolumn{4}{|c|}{ Closure - Non-closure } \\
\hline Rapana venosa biomass $\left(\mathrm{kg} . \mathrm{km}^{-2}\right)$ & 27331491793 & & 13.20 & ** \\
\hline Discard biomass $\left(B-\mathrm{kg} . \mathrm{km}^{-2}\right)$ & 7607217 & 1,60 & 34.69 & $* *$ \\
\hline Discard abundance $\left(N\right.$ - ind. $\left.\mathrm{km}^{-2}\right)$ & 18278 & & 42.55 & $* *$ \\
\hline Species number $(S)^{1}$ & - & & 0.08 & 0.77 \\
\hline The Shannon diversity index $\left(H^{\prime}\right)^{1}$ & - & & 0.82 & 0.36 \\
\hline
\end{tabular}

were significant in regional, seasonal and depth related factors (Kruskal-Wallis, $p<0.001$; Table 2), except for seasonal fishery closure. Although, number of species were not significant among depth and distance from shore, estimated abundance showed a strong differentiation which caused wide range in $H^{\prime}$ among depths and distances. According to results, seasonal closure periods from mid-April to end of August covers critical months for species distribution, and results showed $S$ is the highest during August (summer) while significantly highest abundance and biomass were observed during April and May (spring). Even fishing period is two months longer than closure, estimated discard biomass and abundance were much lower (Table 3).

Multivariate analyses were used to understand distribution pattern of discard composition by each species according to seasonal, regional and depth related factors. Significant one-way ANOSIM results for each factor were considered for further SIMPER analysis to determine species contribution for dissimilarity within groups (Table 4). Seasonality of discard species composition was strong, and shaped by two dominant species as S. inequivalvis and L. depurator (Table 4). The differences between autumn and winter were strongest (ANOSIM, R=0.681, p=0.01) and caused by occurrence of Uronoscopus scaber (Table 4).

\section{Discussion}

Our results indicated that, discard composition of Rapa whelk fishery strongly reflected seasonal changes. Total estimated abundance and biomass values showed significant regional, seasonal and depth related differences, also number of species and diversity index changes regionally and seasonally. S. inaequivalvis, and L. depurator were dominant species and showed different seasonal distribution while $C$. gallina was spatially distributed. Especially, spring season was dominated by $S$. inaequivalvis with very high abundance and biomass, and $L$. depurator was very abundant in summer season. Summer season was very high in number of species, but low in species abundance. Discard ratio in $R$. venosa fishery was found low in biomass. In addition, seasonal fishery closure period was benefited for discard species in spring and summer period. The lowest distribution of $R$. venosa and discard species except $S$. inaequivalvis were found during winter season.

The spawning period of many commercially important species is between May and September in the near coastal habitat of the Black Sea (Genç et al., 2018; Dağtekin et al. 2020). Our results showed seasonal closure period is beneficial for the ecosystem in this respect. Therefore, it is become apparent that seasonal fishery closure is an important indirect management measures both for stock sustainability and ecosystem health. However, collaborative actions are necessary and other Black Sea countries should considered similar implementations in their EEZs.

Normally, fish and other benthic species discards are returned to the sea, whereas smaller bivalves and crabs are collected with the catches. The mortality ratio was found very high in returned species; especially bivalves were losing their ability to bury themselves to mud or sand (Gaspar et al., 2007). Habitat structure is an 
Table 3. Diversity indicators of discard composition during $R$. venosa survey. Species number $(S)$, total estimated abundance ( $N$ ), the Shannon diversity index $\left(H^{\prime}\right)$ and estimated total discard biomass $(B)$ according to each factors as region, season, closure period, depth, and distance from shore.

\begin{tabular}{|c|c|c|c|c|c|}
\hline & Factors & $S$ & $N\left(\right.$ ind. $\left.\mathrm{km}^{-2}\right)$ & $H^{\prime}\left(\log _{e}\right)$ & $B\left(\mathrm{~kg} \cdot \mathrm{km}^{-2}\right)$ \\
\hline \multirow{6}{*}{ Region } & St1 & 21 & 686 & 1.67 & 12943 \\
\hline & St2 & 16 & 428 & 1.76 & 8670 \\
\hline & St3 & 10 & 546 & 0.54 & 11888 \\
\hline & St4 & 5 & 67 & 0.68 & 1517 \\
\hline & St5 & 10 & 605 & 0.46 & 12197 \\
\hline & St6 & 5 & 354 & 0.20 & 7155 \\
\hline \multirow{4}{*}{ Season } & Autumn & 17 & 652 & 1.35 & 13461 \\
\hline & Winter & 7 & 108 & 0.77 & 31020 \\
\hline & Spring & 14 & 1536 & 0.47 & 7375 \\
\hline & Summer & 21 & 390 & 2.07 & 2513 \\
\hline \multirow{2}{*}{ Closure } & Non-fishing & 24 & 1769 & 1.04 & 36823 \\
\hline & Fishing & 19 & 916 & 1.36 & 17547 \\
\hline \multirow{5}{*}{ Depth } & $5-10 m$ & 22 & 697 & 1.75 & 14020 \\
\hline & $10-15 m$ & 16 & 1456 & 0.75 & 29584 \\
\hline & $15-20 m$ & 14 & 417 & 1.14 & 7852 \\
\hline & $20-25 m$ & 6 & 49 & 0.73 & 1430 \\
\hline & $25-30 m$ & 6 & 66 & 0.69 & 1485 \\
\hline \multirow{5}{*}{ Distance } & $0-100 \mathrm{~m}$ & 9 & 55 & 1.72 & 643 \\
\hline & $100-150 \mathrm{~m}$ & 15 & 338 & 1.55 & 5314 \\
\hline & $150-250 \mathrm{~m}$ & 18 & 583 & 1.49 & 11748 \\
\hline & $250-400 \mathrm{~m}$ & 21 & 775 & 1.01 & 16087 \\
\hline & $400 \mathrm{~m}>$ & 14 & 935 & 0.45 & 20578 \\
\hline
\end{tabular}

Table 4. One-way ANOSIM results for significant group of each factors $(p=0.1)$ with $R$ relation and SIMPER results of significant groups with their average dissimilarity (\%) according to species contribution (cut-off 10\%).

\begin{tabular}{|c|c|c|c|c|}
\hline Groups & R Significance Statistics $<0.1$ & Avg. Dissimilarity \% & Species & Contribution \% \\
\hline \multirow{3}{*}{ St.2, St.5 } & \multirow{3}{*}{0.405} & \multirow{3}{*}{68.18} & Scapharca inaequivalvis & 28.87 \\
\hline & & & Liocarcinus depurator & 16.16 \\
\hline & & & Chamelea gallina & 15.11 \\
\hline \multirow{3}{*}{ Summer, Spring } & \multirow{3}{*}{0.614} & \multirow{3}{*}{78.17} & Scapharca inaequivalvis & 32.36 \\
\hline & & & Liocarcinus depurator & 13.91 \\
\hline & & & Chamelea gallina & 11.04 \\
\hline \multirow{3}{*}{ Autumn, Winter } & \multirow{3}{*}{0.681} & \multirow{3}{*}{52.85} & Liocarcinus depurator & 23.93 \\
\hline & & & Scapharca inaequivalvis & 17.31 \\
\hline & & & Uranoscopus scaber & 12.56 \\
\hline \multirow{4}{*}{ Autumn, Spring } & \multirow{4}{*}{0.665} & \multirow{4}{*}{55} & Liocarcinus depurator & 18.81 \\
\hline & & & Scapharca inaequivalvis & 17.53 \\
\hline & & & Chamelea gallina & 12.01 \\
\hline & & & Uranoscopus scaber & 10.51 \\
\hline \multirow{3}{*}{$100-150 \mathrm{~m}, 400 \mathrm{~m}>$} & \multirow{3}{*}{0.474} & \multirow{3}{*}{61.99} & Scapharca inaequivalvis & 23.67 \\
\hline & & & Chamelea gallina & 23.65 \\
\hline & & & Liocarcinus depurator & 14.98 \\
\hline
\end{tabular}

important factor in the variation of discard rates and species composition. (Tiralongo et. al. 2021). Although no turbot fish sample was found in our study, it was determined with high discard ratio on the Bulgarian coast of the Black Sea (Petrova-Pavlova et al., 2020). After the collapse of Mytilus galloprivincialis stocks, $S$. inaequilvalvis and C. gallina are known as the main prey of Rapa whelk (Dağtekin et al 2016). Thus, the distribution of this species closely related with the distribution of its prey items. The samplings of this study were designed according the fishers knowledge of Rapa whelk distribution. The changes in the sampling location, depth and distance from shore were followed Rapa whelk migration pattern and varied month by month. Therefore, the results of this study are highly representative of Rapa whelk fishery discard composition.

\section{Conclusion}

Several research on discards conducted by different fishing gears in the Black Sea, and many fishing methods have more or less discards (Genç et al.2010; Dalgıç \& Ceylan., 2012; Ceylan et al., 2014; Şahin et al., 2015; Eryasar et al., 2018; Petrova-Pavlova et al., 2020). Considering the increase in the Rapa whelk population in the Black Sea, there is a need for studies to support fishing methods with a low discard rate to be accepted by fishers. It is necessary to expand studies on fishing methods such as pot fishery (Saglam et al., 2017), which have been successful in experimental studies in the past. Diving method is preferred in places where the large specimens can be obtained due to the low CPUE and but better profit as the prices of large ones are around 0.50.8 USD. There has been a decrease in many species in 
the Black Sea in recent years, especially the turbot, which is important for small-scale fisheries (GFCM, 2019). The increase in vessel number will have a greater effect even on discards in the next years which indicate this problem should be addressed separately. Discards is a major problem in EU countries with the level of 25$30 \%$ where long term ongoing discussions for implementation of management measures show the solution will not be easy task in near future (EU, 2016). For this, it is recommended to design fishing gear that will protect the resource in the current situation with the support of international organizations such as GFCM and Black Sea Commission and European Union. It is suggested that discard ratios in Rapa whelk fishing should be evaluated in the stock assessment of commercial species. Also, it may be considered to give subsidies to reduce the discard rate in the Rapa whelk fisheries.

\section{Ethical Statement}

This article doesn't contain any experiments on humans and animals.

\section{Funding Information}

This study was supported by General Directorate of Agricultural Research and Policies (TAGEM/HAYSÜD/2016/A11/P-02/04).

\section{Author Contribution}

G.Erik:Conducted field work and data entry, funding Acquisition, Project Administration M.Dağtekin:Conducted field work, analysis, Writing review and editing

\section{Conflict of Interest}

The authors declare that they have no conflict of interest.

\section{Acknowledgements}

The authors thank Özşahin boat's captain and crew for contributing to the sampling. The authors are grateful to the anonymous referee for the valuable input on an earlier version of the article and to Prof. Nazlı Demirel for her valuable contributions analysis and writing process.

\section{References}

Bilecik, N. (1990). Distribution of rapa whelk (Rapana venosa) in the Black Sea coastal of Turkey and effect on Black Sea fisheries. Bodrum Fisheries Institute publication (In Turkish).

BSGM, (2020). https://www.tarimorman.gov.tr/sgb/Belgeler/SagMenu Veriler/BSGM.pdf
Celik, O., \& Samsun, O. (1996). Farklı Dizayn Özelliklerine Sahip Algarnaların Av Veriminin ve Av Komposizyonun Araştırılması. Su Ürünleri Dergisi, 13(3-4), 259-272 (In Turkish).

Ceylan, Y., Şahin, C., \& Kalayci, F. (2014). Bottom trawl fishery discards in the Black Sea coast of Turkey. Mediterranean Marine Science, 15(1), 156-164.

Clarke, K.R. and Warwick, R.M. (2001). Change in Marine Communities: An Approach to Statistical Analysis and Interpretation. 2nd Edition, PRIMER-E, Ltd., Plymouth Marine Laboratory, Plymouth.

Connolly, P.L. \& Kelly, C.J. (1996). Catch and discards from experimental trawl and longline fishing in the deep water of the Rockall Trough. J. Fish. Biol. 49: 132- 144.

Dağtekin M., Erbay M., Dalgıç G., Akpınar Özcan I.,, Aydın M., Özdemir S. \& Karayücel S., 2016. Batı Karadeniz'de (Sinop-Cide) Dağılım Gösteren Beyaz Kum Midyesi (Chamelea gallina (L., 1758)) Stoklarının Tahmini Üzerine Bir Ön Çalışma, TAGEM/HAYSÜD/2011/09/02/05, (pp97), Trabzon.

Dağtekin M., Genç Y., Mısır D.S., Erik G., Ok M. et al. (2020). Doğu Karadeniz'deki Demersal Balık Stoklarının İzlenmesi, TAGEM/HAYSUD/2017/A11/P-02/4 , (pp 141), Trabzon.

Dalgıç, G., \& Ceylan, Y., (2012). Seasonal discards and by-catch of striped venus clam (Chamelea gallina)(Mollusca, Bivalves) fishery in the Black Sea. Turkish Journal of Fisheries and Aquatic Sciences, 12(4), 811-816.

Düzgüneş E., (2001). Rapa whelk Fisheries by dredging in the eastern Black sea. Technological Developments in Fisheries Workshop 19-21 June 2001. (1-11), Izmir Turkey (in Turkish).

Erik G., Dağtekin M., Çankaya A., Genç Y., Mısır S., Kutlu S. (2020). Karadeniz'de Deniz Salyangozu (Rapana venosa, Valenciennes 1846) Balıkçılığının İzlenmesi, TAGEM/HAYSÜD/2016/A11/P-02/04.(67pp), Trabzon.

Eryasar, A. R., Ceylan, Y., Dalgic, G., \& Yesilcicek, T. (2018). Bycatch in the commercial beam trawl fishery for rapa whelk in the Black Sea. Mediterranean Marine Science, 19(1), 69-78.

EU, (2016).

https://www.europarl.europa.eu/RegData/etudes/STU D/2016/573440/IPOL_STU (2016) 573440 EN.pdf

Gaspar, M. B., \& Chícharo, L. M. (2007). Modifying dredges to reduce by-catch and impacts on the benthos. In By-catch Reduction in the World's Fisheries (pp. 95-140). Springer, Dordrecht.

Genç Y., Başçınar N.S., Dağtekin M., Atılgan E. , Akpınar Özcan i., Erbay M. et al. (2018). Doğu Karadeniz'deki Gırgır Balıkçılığını İzleme Projesi, TAGEM/HAYSÜD /2006/09/02/02, Trabzon, (98s) (in Turkish).

Genç, Y., Ak, O., Başçınar, N.S., Dağtekin, M., Erbay, M, Atılgan E. (2010). Doğu Karadeniz'de 2009-2010 Av Sezonunda Avlanılan Hamsi Balığının (Engraulis encrasicolus (L.,1758)), Populasyon Parametreleri Ve Hedef Dışı Av Oranları, SUMAE, 1. Ulusal Hamsi Çalıştayı: Sürdürülebilir Balıkçılık Çalıştay Kitabı., O. Ak, M. Dağtekin (Ed), Su Ürünleri Merkez Araştırma Enstitüsü Müdürlüğü, Yayın No:2010-3, Trabzon, 167s. (In Turkish)

GFCM (2019). WGBS meetings: Turbot Benchmark, BlackSea4Fish Steering Committee, WGBS 8, including turbot TAC, September 16-20, 2020. Trabzon.

ICES (2004). Alien Species Alert: Rapana venosa (veined whelk). Edited by Roger Mann, Anna Occhipinti, and Juliana M. Harding. ICES Cooperative Research Report No. 264. pp 14. 
Kelleher, K. (2005). Discards in the world's marine fisheries. An update. FAO Fisheries Technical Paper No. 470 FAO, 131 pp. Rome.

Pérez Roda, M.A. (ed.), Gilman, E., Huntington, T., Kennelly, S.J., Suuronen, P., Chaloupka, M. \& Medley, P. (2019). A third assessment of global marine fisheries discards. FAO Fisheries and Aquaculture Technical Paper No. 633. Rome, FAO. 78 pp.

Petrova, E., Tserkova, F., Mihneva, V., Stoykov, S., Valchev, S., \& Penchev, P. (2020). Fish bycatch rate by Rapana venosa (Valenciennes, 1846) fishery in the Bulgarian Black Sea waters, with a special emphasis on the bycatch of turbot Scophthalmus maximus (L., 1758). Acta Zool. Bulg., Supplement 15, August 2020: 165-172.

R Core Team (2020). R: A language and environment for statistical computing. R Foundation for Statistical Computing, Vienna, Austria. URL https://www.Rproject.org/

Sağlam, H., Duzgunes, E. \& Ogut, H. (2009) Reproductive ecology of the invasive whelk Rapana venosa Valenciennes, 1846, in the southeastern Black Sea (Gastropoda: Muricidae), ICES Journal of Marine Science, 66: 1865-1867.
Saglam, H., Dagtekin, M., Kutlu, S., Bascinar, S., Sahin, A., \& Duzgunes, E. (2017). Rapa whelk pot fishery in the Black Sea of Turkey: pot type, soak time, depth and season. Cahiers de Biologie Marine, 58(1), 75-81.

Şahin, C., Ceylan, Y., \& Kalaycı, F. (2015). Purse Seine Fishery Discards on the Black Sea Coasts of Turkey. Turkish Journal of Fisheries and Aquatic Sciences, 15(1), 81-91.

Sarda, F., Coll, M., Heymans, J.J. \& Stergiou K.I. (2013). Overlooked impacts and challenges of the new European discard ban. Fish 16:175-180.

STECF. (2017). Scientific, Technical and Economic Committee for Fisheries (STECF) Black Sea assessments (p. 284). Luxembourg: Publications Office of the European Union, EUR 27517 EN, JRC.

Tiralongo, F., Mancini, E., Ventura, D., De Malerbe, S., De Mendoza, F.P., Sardone, M., \& Minervini R. (2021). Commercial catches and discards composition in the central Tyrrhenian Sea: a multispecies quantitative and qualitative analysis from shallow and deep bottom trawling. Mediterranean Marine Science, 22(3), 521-531. 